\title{
Recent Interest Rate Developments
}

OST MARKET interest rates have risen in recent weeks after declining in late July and August and rising sharply earlier this year. This note traces the recent course of interest rates, discusses some causal forces affecting these movements, and comments on the outlook for interest rates.

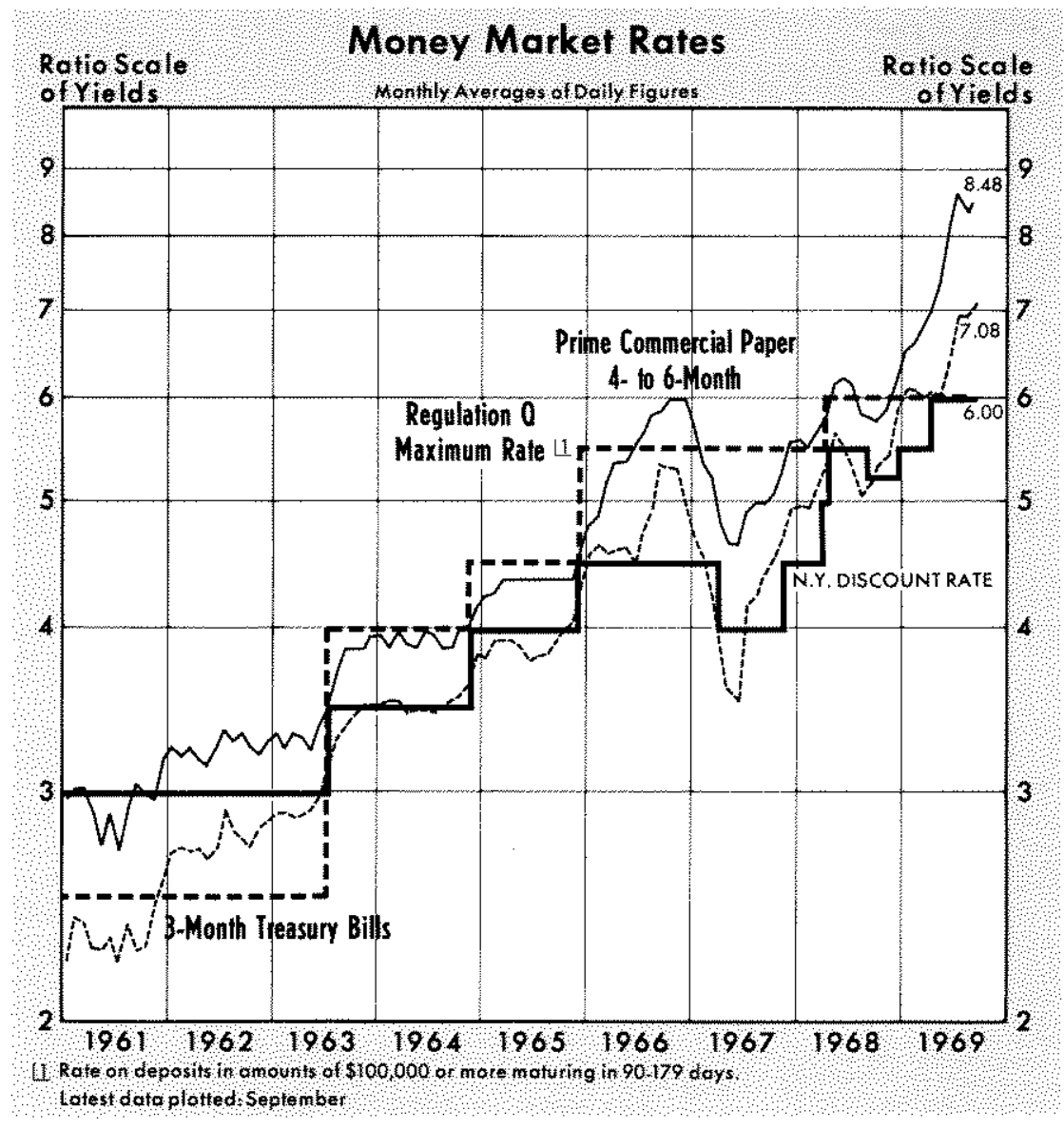

Yields on three-month Treasury bills rose from 5.66 per cent at the end of 1968 to 7.10 per cent during the week ending July 25 . Yields then declined to a low of 6.86 per cent during the week of August 22, and have since moved upward, reaching 7.02 per cent in the first week of October. Yields on commercial paper and bankers' acceptances have shown similar movements. Yields on four- to six-months commercial paper rose from 6 per cent in Dec, 1968 to a peak of $8^{3 / 4}$ per cent in mid-July, retreated to $8 \frac{1 / 4}{4}$ per cent in late August and early September, and recently have climbed back to $83 / 4$ per cent.

Interest rates on long-term securities rose in the first half of the year, drifted lower until late August, and have since risen. In early October, the average yield on long-term Government bonds was 6.56 per cent, up from 6.00 per cent in late August. In early July the average yield was 6.11 per cent, following an increase from 5.55 per cent last December.

Table I summarizes selected interest rate movements over the past year. While other interest rates have generally moved upward, Regulation $Q$ ceiling rates on commercial bank time deposits have remained constant. 


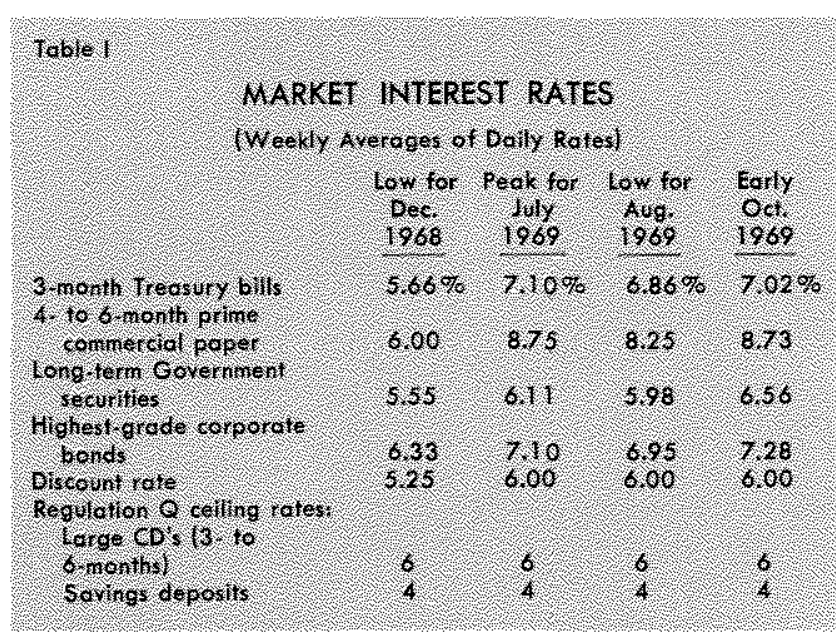

\section{Why Interest Rates Fluctuate}

Market interest rates are the prices of loan funds and, like all unregulated prices, are determined by demand and supply. Numerous factors influence both the demands for and the supply of loan funds, but practically speaking, only a few forces are dominant in most interest rate movements which last for periods of several weeks or more.

Changes in the total demand for loan funds are to a great extent influenced by people's decisions to spend which, in turn, are affected after a lag by monetary actions and by expectations about future returns on investment and future price changes. If entrepreneurs become more optimistic as to future sales and profits, they tend to demand more credit to expand the productive capacity of their plant and equipment and to increase their inventories. A change in expected returns may result from a variety of events, including a break-through in technological research, changing tastes, a more stimulative tax structure, and changing expectations about the influence of stabilization policies on total spending and prices. If expectations change so that future prices are expected to rise faster than had been anticipated previously, demands for credit increase as consumers and businessmen seek to buy goods now, at cheaper prices. ${ }^{1}$

The supply of loan funds is influenced by personal and business saving, by monetary actions, and by actions of commercial banks. Changes in the level of

1William P. Yohe and Denis Kamosky have found, in research conducted at this bank, that current price expectations can be accounted for almost completely by price movements over the two preceding years. savings are influenced significantly by changes in income, with the level of savings rising as income rises and falling as income falls. Changes in saving tend to dampen movements in interest rates. Monetary developments have an impact on interest rates in two different ways. An increase in the supply of base money (the monetary base) increases the banks' demand for earning assets and hence increases the funds supplied to the market by the banks. The volume of loan funds increases in the short run, providing a downward force on interest rates. However, the resulting expansion of banks' holdings of earning assets, other factors constant, results in an increase in the money stock which usually has a longer-run counter influence of pushing interest rates up after several months, since it stimulates spending and the demand for funds.

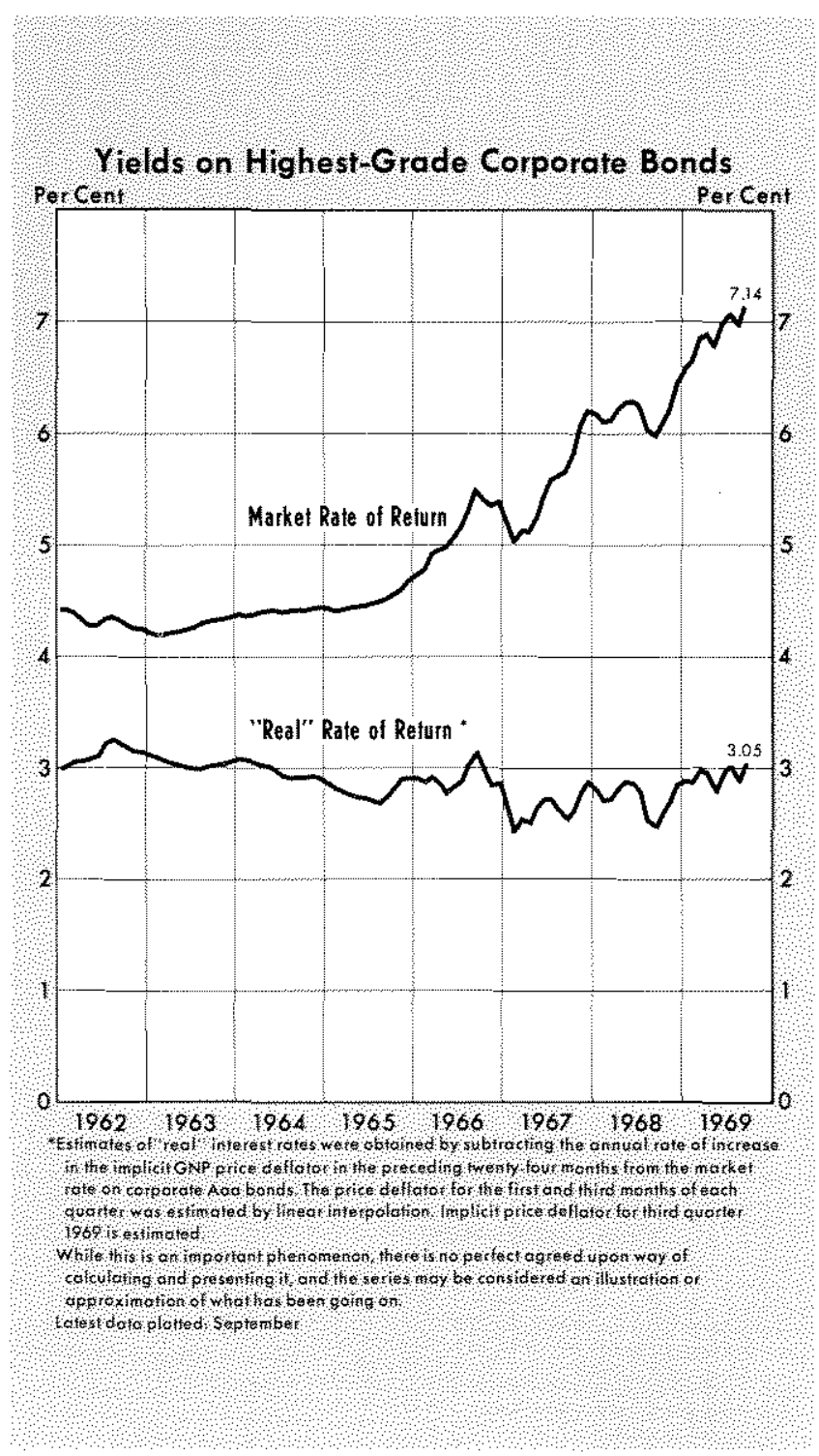




\section{Interest Rate Movements in 1969}

Analyzing the movements in market interest rates since last December, in terms of the demands for and the supplies of loarable funds, is helpful in understanding the economic forces prevalent in the economy.

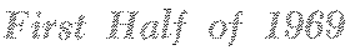

The rise in market interest rates in the first half of the year was due to an accelerating growth in the demand for loan funds while growth in the supply of loan funds moderated. The rise in demand reflected reinforced expectations of accelerating price rises and expectations of higher real returns on capital. These expectations reflected in large part the experience of 1968.

Passage of the surtax in June 1968 had temporarily lowered anticipations about price increases and profitability, and as a result, interest rates remained fairly level for a brief period after mid-1968. But as it became evident that these expectations were not being realized, anticipations regarding demand and price increases were revised upwards, and interest rates rose.

The economy failed to slow in 1968 partly because of expansionary monetary actions. The money stock grew 7 per cent in 1968, about the same as in 1967, and far faster than the trend rate of 2.6 per cent from 1957 to 1967. The monetary expansion in 1968, as

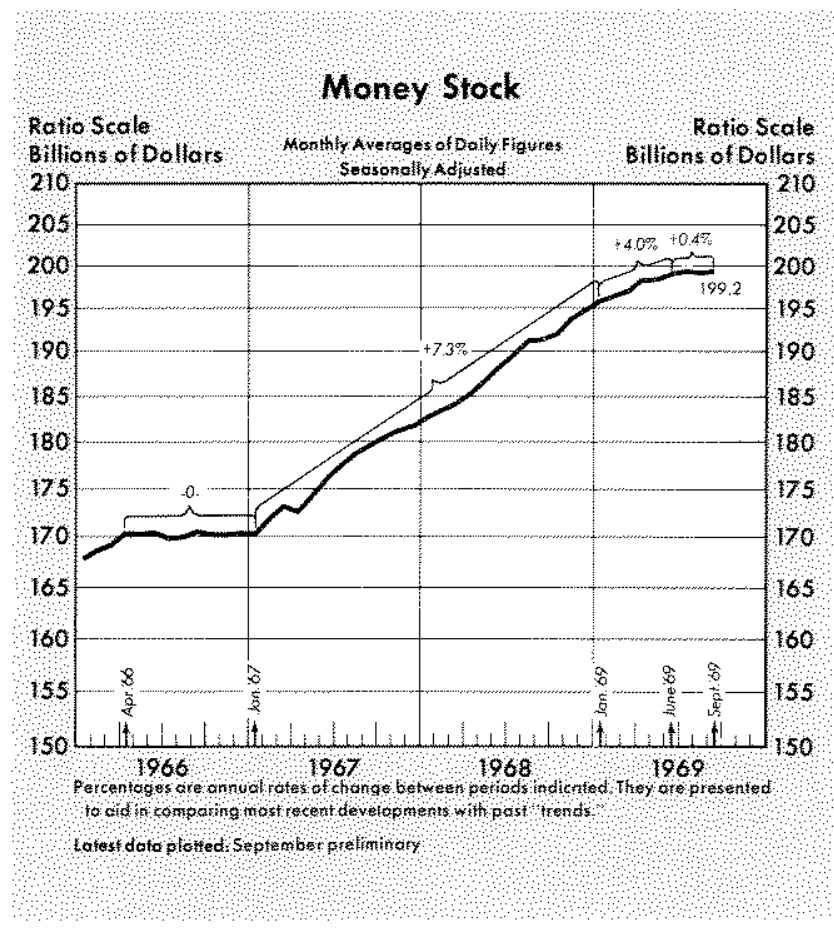

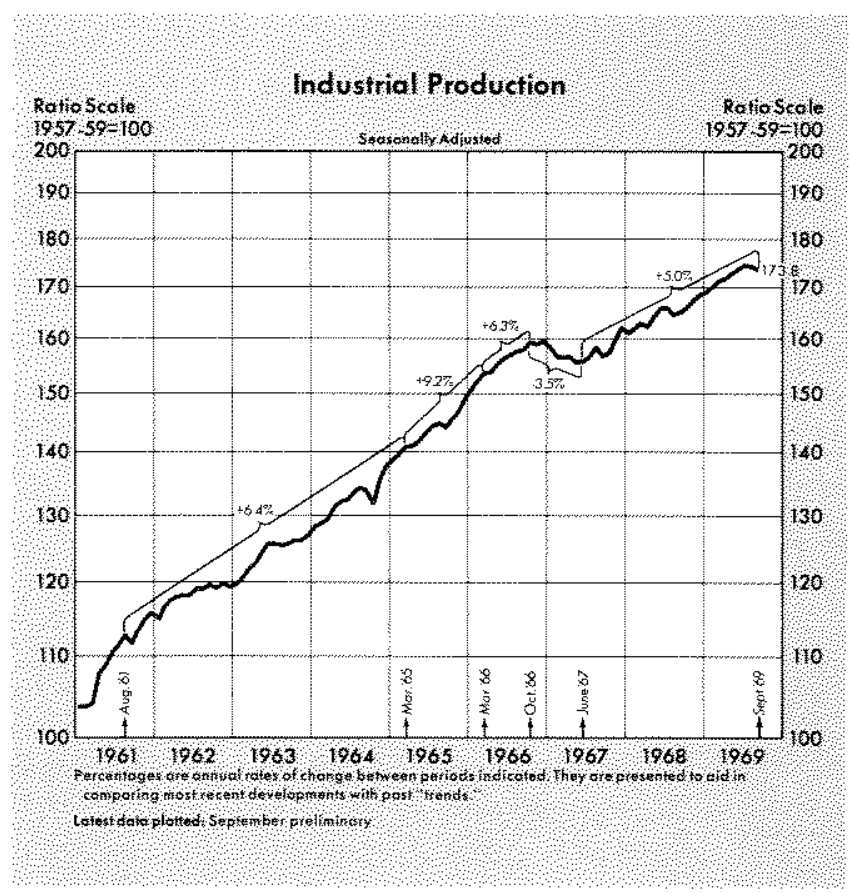

indicated by the growth of the money stock, also stimulated spending and credit demands in early 1969.

Both total spending on goods and services and the price indexes continued to rise rapidly through the first half of 1969. Employment rose at a 2.4 per cent annual rate in the first half of 1969 , continuing the rapid growth of the previous year and a half. Industrial production grew at a 6.1 per cent amual rate in the first six months of the year, even faster than the 4.1 per cent increase in 1968. Personal income rose at an 8.6 per cent annual rate in the first six months of the year, close to the 1968 rate of 9.6 per cent. Demands for credit in the first half of 1969 were also stimulated by the fact that price rises not only failed to slow, but accelerated. Consumer prices rose at a 6.4 per cent annual rate in the first half of 1969 , compared with the 4.7 per cent increase in 1968 and the 1.7 per cent trend rate from 1957 to 1967 .

The total supply of credit probably rose at a slower rate in the first half of 1969 . During this six-month period the money stock rose at a 4.4 per cent annual rate, after growing 7 per cent in 1968 .

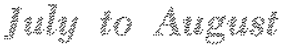

The moderate declines in interest rates in July and August may have resulted primarily from a decrease in the demands for credit. There probably was a temporary lull in demand, following large anticipatory borrowing in May and early June which reflected market expectations of a severe tightening of 
credit around the mid-June tax date. The moderately slower growth in monetary magnitudes in the first half of the year may have had some dampening effect on spending decisions, with corresponding reduction of credit demands. In addition, there may have been some belief that the monetary actions in the first half of the year combined with the continued fiscal restraint, soon would moderate the upward trends of demand and prices.

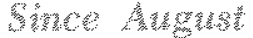

The rise in interest rates since August reflects changes in both supply and demand. The rate of monetary growth has slowed further since June, indicating a reduction in the supply of loanable funds

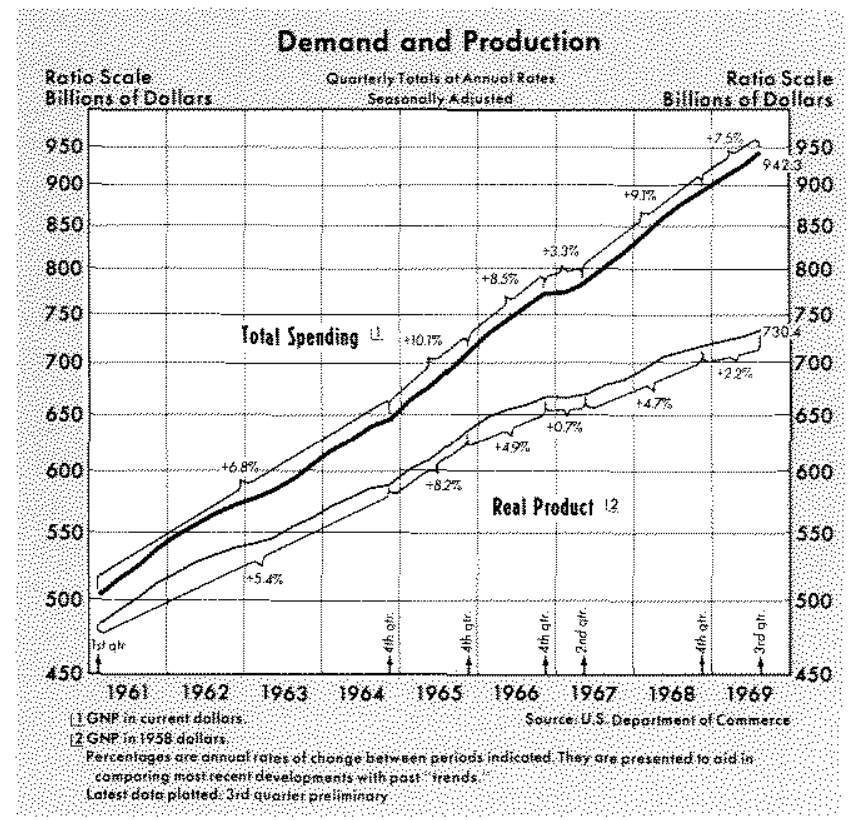

and thereby placing temporary apward pressure on rates. From early June to early October, the money stock was about unchanged.

Demands for loan funds may have increased somewhat since August. Lack of firm indications that total spending was slowing and the continued rapid rise in prices may have increased the demand for credit. Total spending on goods and services rose at a 7.8 per cent annual rate during the third quarter, slightly higher than in the previous two quarters. Capital spending by business firms has remained strong. Consumer prices have risen at a 6 per cent annual rate in 1969, up from a 5 per cent rate in 1968. Overall prices, as measured by the GNP price deflator, rose at a 5.4 per cent rate in the third quarter.

\section{Conclusion and Outlook}

Experience indicates that a reduced growth of monetary magnitudes, such as occurred moderately in the first part of the year and much more intensively since late last spring, will reduce the growth in total spending after several months' lag. With a slower growth in spending, the demand for loan funds falls and the rate of price increases usually slows after some further lag. Expectations of moderated price rises and reduction in the rate of growth in spending may be expected to dampen the very strong demands for credit. When the monetary authorities are convinced that the growth of total spending is no longer excessive, they are likely to provide for moderate growth of the monetary base, tending to add to the supply of loan funds and to place downward pressure on interest rates. 